Article

\title{
Evaluation of Rheological Behavior, Resistance to Permanent Deformation, and Resistance to Fatigue of Asphalt Mixtures Modified with Nanoclay and SBS Polymer
}

\author{
Gabriela Ceccon Carlesso *, Glicério Trichês, João Victor Staub de Melo, Matheus Felipe Marcon, \\ Liseane Padilha Thives and Lídia Carolina da Luz \\ Department of Civil Engineering, Federal University of Santa Catarina, Florianópolis 88040-900, Brazil \\ * Correspondence: gabriela.carlesso@gmail.com; Tel.: +55-49-99133-0706
}

Received: 23 May 2019; Accepted: 27 June 2019; Published: 2 July 2019

\begin{abstract}
Fatigue cracking and rutting are among the main distresses identified in flexible pavements. To reduce these problems and other distresses, modified asphalt mixtures have been designed and studied. In this regard, this paper presents the results of a study on rheological behavior and resistance to permanent deformation and to fatigue of four different asphalt mixtures: (1) with conventional asphalt binder (CAP 50/70); (2) with binder modified by nanoclay ( $3 \% \mathrm{NC}$ ); (3) with binder modified by styrene-butadiene-styrene polymer (SBS 60/85); and (4) with binder modified by nanoclay and SBS ( $3 \%$ NC $+2 \%$ SBS). For this analysis, the mixtures were evaluated based on complex modulus, permanent deformation tests, and fatigue tests $(4 \mathrm{~PB}$, in the four-point bending apparatus), with the subsequent application of numerical simulations. The results obtained show a better rheological behavior related to greater resistance to permanent deformation for the mixture $3 \% \mathrm{NC}+2 \% \mathrm{SBS}$, which could represent an alternative for roads where a high resistance to rutting is required. Otherwise, on fatigue tests, higher resistance was observed for the SBS 60/85 mixture, followed by the $3 \% \mathrm{NC}+2 \%$ SBS mixture. Nevertheless, based on the results of the numerical simulations and considering the possibility of cost reduction for the use of the $3 \% \mathrm{NC}+2 \%$ SBS mixture, it is concluded that this modified material has potential to provide improvements to the road sector around the world, especially in Brazil.
\end{abstract}

Keywords: modified asphalt mixtures; nanomaterials; polymers; rheological behavior; fatigue cracking; permanent deformation

\section{Introduction}

Rutting and fatigue cracking can be considered the main distresses of flexible pavements. Besides reducing the safety and comfort of roadway users, it results in a need for increased vehicle maintenance.

In the search for better performance of asphalt coatings in relation to these problems, besides a higher strength to reduce other defects, the use of modified asphalt mixtures is one option available. In this context, asphalt mixtures modified with polymers have been applied successfully to road engineering since the 1970s, when they were first used in Europe [1]. In recent years, with the advent of nanotechnology, modification with the use of nanomaterials has also gained the attention of the scientific community. Studies carried out with asphalt nanocomposites have demonstrated the good performance and potential of these materials in the paving sector [2-12]. More recently, the behavior of asphalt binders and mixtures modified with polymers and nanomaterials have been investigated. The results obtained in this line of research have also been positive [13-21]. However, most studies have been limited to the binders, and there is a need for more investigations that consider the mixtures, taking 
into account the interaction between the binder, the granulometry, and the aggregate characteristics. This is important and should be considered because the total composition of the asphalt mixture will be in contact with traffic and weather during the pavement's lifespan, although the binder characteristics have a prominent role.

Thus, considering the high performance of mixtures modified with the addition of polymers and the potential for the application of nanomaterials to road engineering, the aim of this study was to carry out a comparative analysis of the rheological behavior and resistance to permanent deformation and to fatigue of four different asphalt mixtures: (1) a reference mixture, produced with a conventional asphalt binder (CAP 50/70: Petroleum Asphalt Cement with a penetration range between 5.0 and 7.0 millimeters) [22]; (2) a mixture with binder modified by nanoclay ( $3 \% \mathrm{NC})$, produced in laboratory [22]; (3) a mixture with binder modified by the polymer styrene-butadiene-styrene (SBS $60 / 85$, with a minimum softening point of $60^{\circ} \mathrm{C}$ and a minimum elastic recovery of $85 \%$ ), produced industrially [23]; and (4) a mixture with binder modified by nanoclay and SBS ( $3 \% \mathrm{NC}+2 \% \mathrm{SBS}$ ), also produced in the laboratory [24]. This analysis was carried out through complex modulus and fatigue tests (4 PB, in the four-point bending apparatus) and permanent deformation tests (in the LCPC (Central Laboratory of Bridges and Roads/Laboratoire Central des Ponts et Chaussées) traffic simulator). Besides evaluating the behavior of the complex modulus and the phase angle of the mixtures with variations in the test load frequency and temperature, the rheological study allowed the prediction of the resistance of asphalt mixtures, especially with regard to rutting.

\section{Materials and Methods}

\subsection{Materials}

\subsubsection{Aggregates and Granulometric Composition}

The aggregates used in the production of the asphalt mixtures are of basaltic origin. The characterization of these materials is provided in Table 1. It can be observed that the properties listed are in conformity with the criteria established by the Superpave methodology (whenever applicable), verifying the suitability of the aggregates for the formulation of the mixtures.

Table 1. Characterization of aggregates [22].

\begin{tabular}{cccc}
\hline Property & Standard & Result & Superpave Criterion \\
\hline Bulk density of coarse aggregate & ASTM C 127 [25] & $2.953 \mathrm{~g} / \mathrm{cm}^{3}$ & $\mathrm{n} / \mathrm{a}$ \\
Apparent density of coarse aggregate & ASTM C 127 [25] & $2.880 \mathrm{~g} / \mathrm{cm}^{3}$ & $\mathrm{n} / \mathrm{a}$ \\
Absorption of coarse aggregate & ASTM C 127 [25] & $0.8 \%$ & $\mathrm{n} / \mathrm{a}$ \\
Bulk density of fine aggregate & DNER-ME 084 [26] & $2.974 \mathrm{~g} / \mathrm{cm}^{3}$ & $\mathrm{n} / \mathrm{a}$ \\
Bulk density of powdery material & DNER-ME 085 [27] & $2.804 \mathrm{~g} / \mathrm{cm}^{3}$ & $\mathrm{n} / \mathrm{a}$ \\
Angularity of coarse aggregate & ASTM D 5821 [28] & $100 \% / 100 \%$ & $100 \% / 100 \%$ min. ${ }^{1}$ \\
Angularity of fine aggregate & ASTM C 1252 [29] & $49.2 \%$ & $45 \%$ min. \\
Flat and elongated particles & ABNT NBR 6954 [30] & $9.6 \%$ & $10 \% \max$. \\
Clay content (Sand equivalent) & AASHTO T 176 [31] & $61.2 \%$ & $50 \% \min$. \\
Hardness (Los Angeles abrasion) & ASTM C 131 [32] & $11.6 \%$ & $35-45 \% \max$. \\
Soundness & ASTM C 88 [33] & $2.1 \%$ & $10-20 \% \operatorname{max.}$ \\
Deleterious materials & AASHTO T 112 [34] & $0 \%$ & $0.2-10 \% \operatorname{max.}$ \\
\hline
\end{tabular}

Note: ${ }^{1}$ e.g.,: $85 \% / 80 \%$ means that $85 \%$ of coarse aggregate has one or more fractured faces and $80 \%$ has two or more fractured faces.

Table 2 presents the characterization of the hydrated lime used in the study, which corresponds to type $\mathrm{CH}-1$ dolomitic. 
Table 2. Characterization of the hydrated lime [22].

\begin{tabular}{cc}
\hline Property & Result \\
\hline Loss on ignition & $18.6 \%$ \\
Insoluble residue & $1.9 \%$ \\
Carbon dioxide $\left(\mathrm{CO}_{2}\right)$ & $2.5 \%$ \\
Calcium oxide $(\mathrm{CaO})$ & $45.1 \%$ \\
Magnesium oxide $(\mathrm{MgO})$ & $33.5 \%$ \\
Total non-volatile oxides $(\mathrm{CaO}+\mathrm{MgO})$ & $96.5 \%$ \\
Total non-hydrated oxides & $27.6 \%$ \\
Non-hydrated $\mathrm{CaO}$ & $0.0 \%$ \\
Calcium $(\mathrm{Ca})$ & $32.2 \%$ \\
Magnesium $(\mathrm{Mg})$ & $20.2 \%$ \\
Bulk Density & $3.00 \mathrm{~g} / \mathrm{cm}^{3}$ \\
\hline
\end{tabular}

The formulation of the asphalt mixtures, based on the granulometric curve shown in Figure 1, was comprised of $43 \%$ gravel, $15.5 \%$ of crushed gravel, $40 \%$ of grit, and $1.5 \%$ of lime. This composition was established by the Leopoldo Américo Miguez de Mello Research and Development Center (CENPES/Petrobras), which aimed at obtaining mixtures with a high resistance to permanent deformation. The granulometric curve, aggregates, and hydrated lime were chosen because they were also applied in an experimental monitored road stretch still under evaluation by the authors.

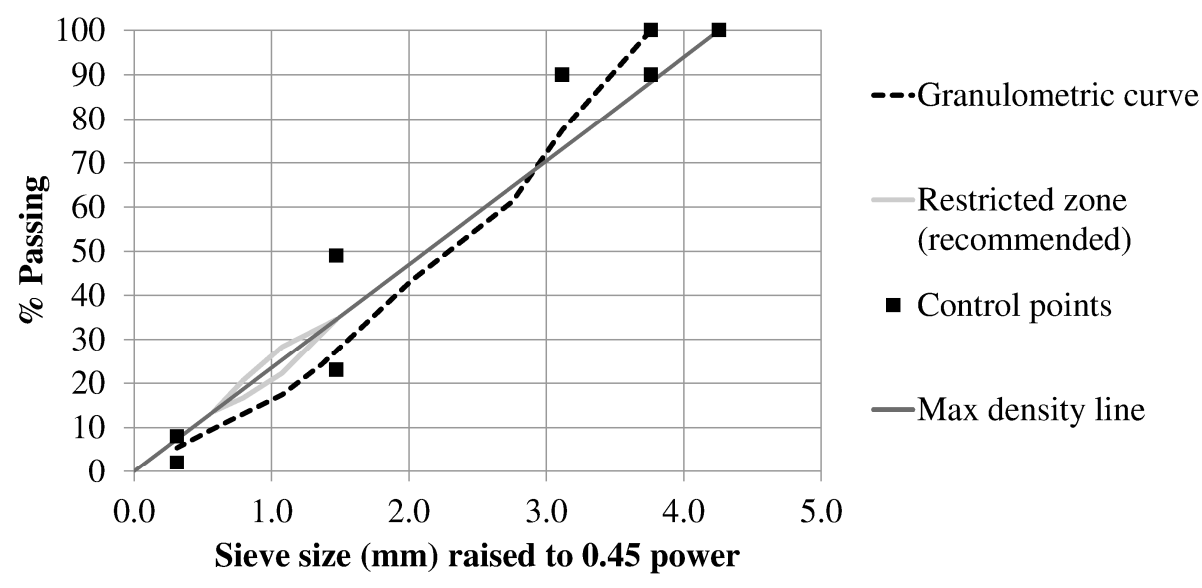

Figure 1. Granulometric curve for aggregate composition.

\subsubsection{Conventional Asphalt Binder}

The conventional asphalt binder used in this study was a CAP 50/70 (Petroleum Asphalt Cement with a penetration range between 5.0 and 7.0 millimeters), with PG 58-22 (Performance Grade 58-22). This binder was used in the production of the reference asphalt mixture and as a matrix for the modification of $3 \% \mathrm{NC}$ and $3 \% \mathrm{NC}+2 \%$ SBS binders. The asphalt binder characterization is shown in Table 3.

\subsubsection{Asphalt Binder Modified with SBS Polymer}

The binder modified with the SBS polymer was industrially produced and supplied by Greca Asfaltos S.A. The characterization of this material is provided in Table 4. 
Table 3. Characterization of the conventional asphalt binder (CAP 50/70).

\begin{tabular}{cccc}
\hline Property & Unit & Standard & Result \\
\hline Penetration & $0.1 \mathrm{~mm}$ & ASTM D 5 [35] & 57 \\
Softening point & ${ }^{\circ} \mathrm{C}$ & ASTM D 36 [36] & 47.9 \\
Thermal susceptibility index & - & - & -1.44 \\
Brookfield viscosity & & & \\
at $135^{\circ} \mathrm{C}$ (spindle 21, 20 rpm) & $\mathrm{cP}$ & ASTM D 4402 [37] & 290 \\
at $150^{\circ} \mathrm{C}$ (spindle 21, 50 rpm) & & & 150 \\
at $175{ }^{\circ} \mathrm{C}($ spindle 21, 100 rpm) & & & 60 \\
\hline
\end{tabular}

Table 4. Characterization of the asphalt binder modified by styrene-butadiene-styrene (SBS) polymer (SBS 60/85).

\begin{tabular}{cccc}
\hline Property & Unit & Standard & Result \\
\hline Penetration & $0.1 \mathrm{~mm}$ & ASTM D 5 [35] & 50 \\
Softening point & ${ }^{\circ} \mathrm{C}$ & ASTM D 36 [36] & 73.0 \\
Elastic recovery & $\%$ & ABNT NBR 15086 [38] & 90 \\
Apparent viscosity & & & \\
at $135^{\circ} \mathrm{C}($ spindle 21, 20 rpm) & $\mathrm{CP}$ & ASTM D 4402 [37] & 1910 \\
at $150^{\circ} \mathrm{C}($ spindle 21, 50 rpm) & & & 640 \\
at $175{ }^{\circ} \mathrm{C}($ spindle 21, 100 rpm) & & & 290 \\
\hline
\end{tabular}

\subsubsection{Modifiers}

The organophillic nanoclay used in the modification of CAP 50/70 is known commercially as Dellite 67G. It has a particle size (dry) of 7-9 $\mu \mathrm{m}$, a particle size after dispersion of $1 \times 500 \mathrm{~nm}$, and density of $1.7 \mathrm{~g} / \mathrm{cm}^{3}$. It has the following chemical composition: carbon $(45.50 \%)$, silica $(33.42 \%)$, aluminum $(16.08 \%)$, iron $(3.60 \%)$, chloride $(0.80 \%)$, titanium $(0.31 \%)$, potassium $(0.27 \%)$, and strontium $(0.02 \%)$. According to the results of thermogravimetry tests, this nanomaterial is thermally stable at temperatures below $262.4{ }^{\circ} \mathrm{C}$ [22].

The polymer SBS used as a modifier was Kraton D1101. It has a linear structure, with a polystyrene content of between $30 \%$ and $32 \%$, and it was supplied in granules.

\subsection{Methods}

This study was carried out in seven stages.

Firstly, in Stage 1, the modification of the conventional binder and the characterization of the modified binders were carried out. In this stage, the binders 3\% NC (modified by $3 \%$ nanoclay in relation to the weight of CAP 50/70) and $3 \%$ NC $+2 \%$ SBS (modified by $3 \%$ of nanoclay and $2 \%$ of SBS polymer) were obtained. The content of nanoclay was established as $3 \%$ based on the results of a previous optimization study developed by Melo [22], who evaluated the permanent deformation resistance of asphalt mixtures produced with binders modified by $1 \%, 2 \%$, and $3 \%$ of nanoclay and verified a better performance for the $3 \% \mathrm{NC}$ mixture. This nanoclay content was also identified in a recent study [39] as the most frequent value mentioned in the related literature. The addition of $2 \%$ SBS together with 3\% NC was aimed at obtaining an asphalt material with elastic recovery. Low polymer content was adopted based on results reported by Pamplona et al. [20], who studied the modification with $2.5 \%$ of nanoclay and $2.5 \%$ of SBS, and also for economic reasons. It means the authors would like to produce a binder with reduced polymer content due to the cost of this material. However, another optimization of the modifier amount, including the SBS content, is recommended for future studies.

The inclusion of nanoclay and the polymer SBS in the base binder CAP 50/70 was carried out in a laboratory high shear mixer (Silverson, model L5M-A), and the modification procedures were defined based on studies reported in the literature $[5,11,12,15-20]$. The modification to produce the $3 \%$ NC 
binder was carried out at $150{ }^{\circ} \mathrm{C}$, with a shearing speed of $5000 \mathrm{rpm}$ and compatibilization period of $100 \mathrm{~min}$. In this regard, the previously mentioned literature review study [39] also identified the following values as more frequent in similar studies: temperature of $160^{\circ} \mathrm{C}$, mixing speed of $4000 \mathrm{rpm}$, and mixing process duration of $120 \mathrm{~min}$. This indicates this work is consistent with the literature, since the adopted and mentioned values are close. In the case of the $3 \% \mathrm{NA}+2 \% \mathrm{SBS}$ binder, a modification temperature of $180^{\circ} \mathrm{C}$ and a mixing period of $180 \mathrm{~min}$ were adopted, maintaining the shearing speed of $5000 \mathrm{rpm}$. These differences in time and temperature of modification were established in order to allow the complete dispersion of the modifiers. However, it should be noted that this can also do some influence on the binders and mixtures behavior. It is also interesting to mention that, as the binders were produced using a laboratory high shear mixer, for the reproduction of these materials in large quantities, with the same characteristics and aiming at the adequate dispersion of the modifiers, it would be necessary to use of an industrial high-shear mixer or another solution that provides the same results in terms of modifiers dispersion.

After production, the modified binders were then characterized according to the following properties: penetration (ASTM D 5 [35]), softening point ASTM D 36 [36]), elastic recovery (ABNT NBR 15086 [38]), phase separation (ABTN NBR 15166 [40]), and apparent viscosity (ASTM D 4402 [37]).

Stage 2 consisted of establishing the design binder contents of the asphalt mixtures, beginning the part of this study that aims to evaluate the influence of the modifiers when interacting in the asphalt mixtures. For this, the Superpave mix design method was applied, according to the standards AASHTO M 323 [41] and AASHTO R 35 [42], with the use of a gyratory compactor. Considering a maximum nominal size of the aggregate of $19 \mathrm{~mm}$ and a heavy volume of traffic, the binder contents of the design correspond to the following dosage criteria that were met simultaneously: (1) percentage of void volume in Ninitial (9 spins, Vv@Ninitial) > 11.0\%; (2) percentage of void volume in Ndesign $(125$ spins, Vv@Ndesign $)=4.0 \%$; (3) voids in mineral aggregate $(\mathrm{VMA}) \geq 13.0 \%$; (4) voids filled with asphalt (VFA) between $65 \%$ and $75 \%$; and (5) dust to effective binder ratio between 0.8 and 1.6. It is important to note that, during the design mix and the subsequent steps, the asphalt mixtures were produced and compacted at temperatures of which the binder viscosities corresponded respectively to 0.17 Pa.s and 0.28 Pa.s.

In Stage 3, after the design binder content definition, for each mixture, three plates were molded with one having dimensions of $60 \times 40 \times 9 \mathrm{~cm}$ (for sawing and obtaining prismatic specimens for the complex modulus and fatigue tests) and two plates having dimensions of $50 \times 18 \times 5 \mathrm{~cm}$ (for the permanent deformation tests). This molding was carried out at the LCPC compacting table, following the recommendations of the French standard AFNOR NF P 98-250-2 [43] for a heavy traffic highway. Plates with dimensions $60 \times 40 \times 9 \mathrm{~cm}$ were then sawn, and five specimens with dimensions close to $6.3 \times 5.0 \times 40.0 \mathrm{~cm}$ were obtained from each plate.

In Stage 4, the rheological behavior characterization of the different mixtures was evaluated. This characterization was based on complex module tests, carried out in a four-point bending test machine, following the recommendations of the European standard EN 12697-26 [44]. For each asphalt mixture, two specimens produced in the previous stage were tested. These tests were carried out under alternating bending with the application of sinusoidal loading keeping the deformation amplitude at $50 \mu \varepsilon$. Temperatures of $0{ }^{\circ} \mathrm{C}, 5{ }^{\circ} \mathrm{C}, 10^{\circ} \mathrm{C}, 15^{\circ} \mathrm{C}, 20^{\circ} \mathrm{C}, 25^{\circ} \mathrm{C}$, and $30^{\circ} \mathrm{C}$ with load frequencies of $0.1 \mathrm{~Hz}, 0.2 \mathrm{~Hz}, 0.5 \mathrm{~Hz}, 1 \mathrm{~Hz}, 2 \mathrm{~Hz}, 5 \mathrm{~Hz}, 10 \mathrm{~Hz}$, and $20 \mathrm{~Hz}$, were evaluated. For the interpretation of the results, master curves and black spaces were analyzed. The master curves were built in the reference temperature of $20^{\circ} \mathrm{C}$, based on the TTS principle (time-temperature superposition) and by applying the Williams-Landel-Ferry equation, of which the constants were calculated using the Viscoanalyse software (developed by the LCPC).

In Stage 5, the resistance to permanent deformation of the four different mixtures was evaluated. In this stage, tests were performed in the French traffic simulator following the standard EN 12697-22+A1 [45]. These tests were carried out at $60{ }^{\circ} \mathrm{C}$, with the application of a single axle with single wheel load, intensity of $5 \mathrm{kN}$, tire inflation pressure of $0.6 \mathrm{MPa}$, and frequency of $1 \mathrm{~Hz}$. 
The development of rutting recesses was measured after the following numbers of cycles: 100, 300, $1000,3000,10,000$, and 30,000. The results of these tests after 30,000 cycles were compared to the limits established by the French [46] and European [47] guidelines.

Stage 6 consisted in evaluating the fatigue resistance of the asphalt mixtures. As mentioned for the rheological characterization, fatigue tests were also carried out in four-point bending test machine but followed the recommendations of the European standard EN 12697-24 [48]. In this stage of the study, about fifteen specimens were tested for each mixture under controlled deformation at deformation levels between 80 and $375 \mu \varepsilon(\mu \mathrm{m} / \mathrm{m})$. These tests were performed considering a frequency of $10 \mathrm{~Hz}$ (simulating the vehicles speed, in practice, of $72 \mathrm{~km} / \mathrm{h} \mathrm{[49])} \mathrm{and} \mathrm{at} \mathrm{the} \mathrm{temperatures} \mathrm{between} 15^{\circ} \mathrm{C}$ and $20^{\circ} \mathrm{C}$ (defined according to the average temperature of the region of this study). As a rupture criterion, it adopted a reduction of $50 \%$ of the initial complex modulus. At the end of the tests, it was possible to obtain the fatigue models of the mixtures, as presented in Equation (1):

$$
N=k(\mu \varepsilon)^{-n}
$$

where $N=$ number of cycles (loading applications) until asphalt concrete reaches $50 \%$ of initial stiffness; $\mu \varepsilon=$ maximum tensile strain applied on the material; and $k, n=$ constants mainly dependent on stiffness and asphalt content of the mixture.

After that, in Stage 7, numerical simulations were carried out, considering the structures presented in Figure 2 (S1, S2, S3, and S4 with the same subgrades, subbases, and bases but different asphalt layers). These structures were chosen for analysis and comparisons because they represent variations of the structure S1, which was constructed in a roadway in the region where the authors developed this work and where the asphalt surface presents early distresses. This road stretch with the structure $\mathrm{S} 1$ is being monitored by the authors in other projects. The simulations aimed at estimating the tensile strain suffered by the lower fibers of the asphalt layers during the passage of vehicles (at $170 \mathrm{~mm}$ depth, according Figure 2). Thus, in the simulations, it was considered the load configuration shown in Figure 3, at the speed of $20 \mathrm{~m} / \mathrm{s}$ and the fatigue tests' temperature. Applying this stage results to the fatigue models obtained in Stage 6, it was possible to estimate the lifespan in terms of asphalt concrete fatigue fracture of each structure analyzed. This procedure represents an initial estimation for comparisons, and lab to site shift factors can be applied in future researches. It also should be noted that the viscoelastic behavior of the asphalt mixtures was considered in the simulations by using the Huet-Sayegh rheological parameters, obtained from the results of Step 5.

S2
Subbase
E $=210 \mathrm{MPa}, v=0.35$
Subgrade
$\mathrm{E}=260 \mathrm{MPa}, v=0.35$
Surface $2 \times 180 \mathrm{MPa}, v=0.35$

Surface 1: asphalt mixture with convencional binder (CAP $50 / 70)$
Surface 2: asphalt mixture with binder modified by nanoclay $(3 \% \mathrm{NC})$
Surface 3: asphalt mixture with binder modified by SBS (SBS $60 / 85)$
曲 Surface 4: asphalt mixture with binder modified by nanoclay and SBS ( $3 \% \mathrm{NC}+2 \% \mathrm{SBS}$ )
*Note: $\mathrm{E}=$ elastic modulus, $v=$ Poisson's ratio

Figure 2. Pavement structures evaluated in the numerical simulations. 
(a) Perspective

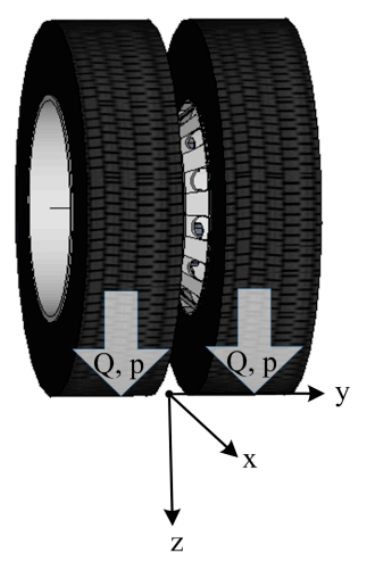

(b) Top view

$$
\because-320 \mathrm{~mm} \rightarrow
$$

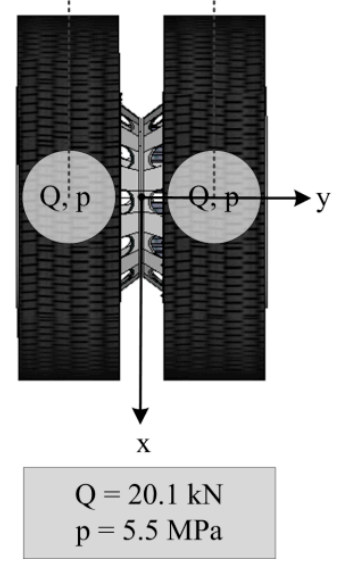

(c) Side view

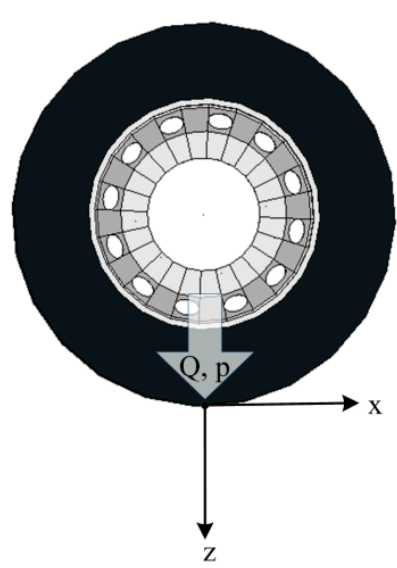

Figure 3. Load configuration considered for the numerical simulations.

\section{Results and Discussion}

\subsection{Characterization of Modified Binders}

Results of the laboratory modified asphalt binders' characterization can be observed in Table 5 .

Table 5. Characterization of asphalt binders $3 \% \mathrm{NC}$ and $3 \% \mathrm{NC}+2 \% \mathrm{SBS}$.

\begin{tabular}{ccccc}
\hline Propriety & \multirow{2}{*}{ Unit } & Standard & \multicolumn{2}{c}{ Asphalt Binder } \\
& & & 3\% NC & 3\% NC + 2\% SBS \\
\hline Penetration & $0.1 \mathrm{~mm}$ & ASTM D 5 [35] & 55 & 36 \\
Softening point & ${ }^{\circ} \mathrm{C}$ & ASTM D 36 [36] & 50.2 & 56.9 \\
Elastic recovery & $\%$ & ABNT NBR 15086 [38] & 6 & 49 \\
Phase separation (24 h/48 h) & ${ }^{\circ} \mathrm{C}$ & ABNT NBR 15166 [40] & $1.0 /-$ & $0.5 / 0.8$ \\
Apparent viscosity & & & & \\
at $135{ }^{\circ} \mathrm{C}($ spindle 21, 20 rpm) & $\mathrm{CP}$ & ASTM D 4402 [37] & 410 & 760 \\
at $150^{\circ} \mathrm{C}($ spindle 21,50 $\mathrm{rpm})$ & & & 90 & 370 \\
at $175^{\circ} \mathrm{C}$ (spindle 21, 100 rpm) & & & 90 & 160 \\
\hline
\end{tabular}

In comparing the results in Table 5 with those provided for the empirical characterization of CAP 50/70 (Table 3) and SBS 60/85 (Table 4), it can be observed that, as expected and also demonstrated by other authors in similar studies [13-21], the binders modification caused a penetration decrease and a softening point increase. Notable among these results are the relatively low penetration obtained for the binder $3 \% \mathrm{NC}+2 \%$ SBS and the relatively high softening point for the binder SBS $60 / 85$. This reflects gains in the stiffness in the first case in contrast with gains related to the sensitivity to high temperatures in the second case. These characteristics indicate that the asphalt mixtures formulated will be very resistant to permanent deformation. Thus, according to the results obtained in the empirical characterization of the binders, better performance is expected in relation to the permanent deformation for the mixtures SBS $60 / 85$ and $3 \%$ NC $+2 \%$ SBS. However, it is important to highlight that the behavior prediction of asphalt mixtures based on the modified binders' empiric characterization shows high limitations.

In relation to the elastic recovery property, the obtainment of a higher value is observed for the binder SBS 60/85. This result is due to the relatively high content of the elastomeric polymer added to the material (approximately $4 \%$ ). On the other hand, the low elastic recovery of the binder $3 \% \mathrm{NC}$ is related to the fact that, in the modification, the nanoclay does not function as an elastomeric product.

With regard to storage stability, the tests carried out with binders modified by nanoclay ( $3 \%$ $\mathrm{NC}$ and $3 \% \mathrm{NC}+2 \% \mathrm{SBS}$ ) revealed that they do not show significant phase separation. By way of 
comparison, it can be noted that the results are below the maximum limit $\left(5^{\circ} \mathrm{C}\right)$ established by the Brazilian Specification for Asphalt-Polymer [50].

In the same way, the results obtained for the modified binders' viscosity also met the limits established by the Brazilian Specification for Asphalt-Polymer [50] despite the considerable increases in comparison to CAP 50/70 (conventional).

\subsection{Definition of Binder Contents}

Table 6 shows the design binder contents obtained for the mixtures.

Table 6. Design binder contents of different asphalt mixtures.

\begin{tabular}{cc}
\hline Asphalt Binder & Design Binder Content (\%) \\
\hline CAP 50/70 & 4.4 \\
$3 \%$ NC & 4.1 \\
SBS 60/85 & 4.5 \\
$3 \%$ NC $+2 \%$ SBS & 4.3 \\
\hline
\end{tabular}

As can be observed in Table 6, the nanoclay addition to the conventional binder can lead to a reduction in the design binder content. In contrast, with the polymer SBS addition, higher binder content is required. Thus, the intermediate result obtained for the $3 \% \mathrm{NC}+2 \%$ SBS mixture in the design mix study demonstrates the combination of the nanoclay positive effect, in terms of mixture workability, with the negative effect of the presence of the polymer.

Also concerning the different binder contents obtained for the mixtures it should be noted that their rheological behavior, resistance to permanent deformation and resistance to fatigue (whose results will be presented later) can be influenced because the mixtures were not produced with exactly the same binder content (an exception to this comment are the mixtures CAP 50/70 and 3\% NC, which were both produced with the same binder content $=4.4 \%$ ). However, it's important to highlight the previously mentioned variation in the design binder contents is meeting the limit values allowed in the field $( \pm 0.3 \%)$, based on Brazilian current construction specifications.

\subsection{Plate Molding}

Table 7 reports the results of void volume percentages checked for the specimens used in the complex modulus and fatigue tests. Table 8 also reports the results of void volume percentages but, in this case, obtained for the plates used in the permanent deformation tests.

Table 7. Volumetric characterization of specimens used in complex modulus and fatigue tests.

\begin{tabular}{ccc}
\hline Asphalt Mixture & Mean & $\begin{array}{c}\text { Void Volume (\%) } \\
\text { Standard Deviation }\end{array}$ \\
\hline CAP 50/70 & 4.53 & 0.87 \\
3\% NC & 3.85 & 0.38 \\
SBS 60/85 & 4.62 & 0.39 \\
$3 \%$ NC + 2\% SBS & 3.83 & 0.54 \\
\hline
\end{tabular}

It should be noted that the plates molded to obtain specimens (modulus and fatigue tests) and those molded for permanent deformation tests were produced by aiming at $4 \%$ void volumes, as defined in the design mix study. However, during the compaction procedure, carried out at the LCPC compacting table (compaction procedure different from that used in the mixtures design step), it was found to be difficult to control the final thickness of the plates, hindering the precise obtainment of the void volumes equal to $4 \%$. Even so, considering that the specimens and plates met the compaction degrees admitted in the field in Brazil (between 97\% and 101\%), they were considered suitable for use in the tests. 
Table 8. Volumetric characterization of plates used in permanent deformation tests.

\begin{tabular}{ccc}
\hline Asphalt Mixture & Plate & Void Volume (\%) \\
\hline \multirow{2}{*}{ CAP 50/70 } & P1 & 6.13 \\
& P2 & 4.50 \\
3\% NC & P1 & 6.55 \\
& P2 & 6.68 \\
SBS 60/85 & P1 & 5.87 \\
& P2 & 5.57 \\
$3 \%$ NC + 2\% SBS & P1 & 5.37 \\
& P2 & 5.69 \\
\hline
\end{tabular}

\subsection{Rheological Characterization}

Figure 4 shows the master curves obtained for the asphalt mixtures evaluation. In general, the positioning of the curves indicates higher stiffness for the modified asphalt mixtures. An exception, however, is the mixture SBS 60/85 which, at high load frequencies (equivalent to low temperatures), shows a very similar rheological behavior to the conventional mixture. In comparison with the other studied mixtures, the mixture $3 \% \mathrm{NC}+2 \%$ SBS showed notably high values for the complex modulus. This characteristic can be considered as an indication that the mixture will have greater resistance to permanent deformation but can be hampered in terms of fatigue resistance.

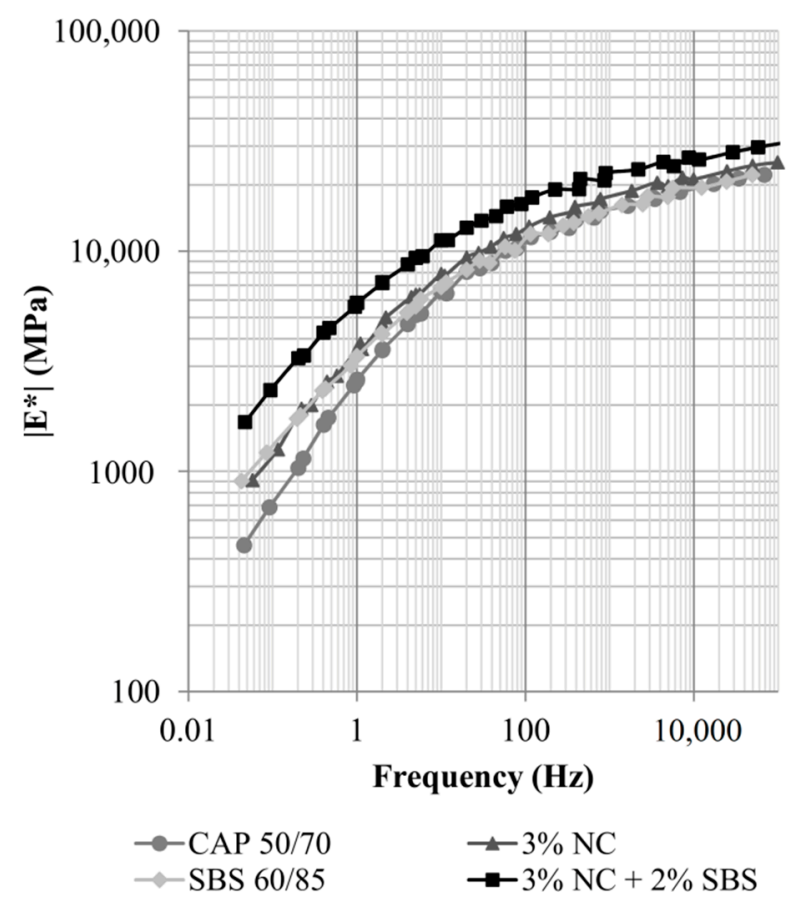

Figure 4. Master curves (reference temperature $=20^{\circ} \mathrm{C}$ ).

In addition, an analysis of the master curves also reveals the lower frequency susceptibility of the modified mixtures based on the slopes of the curves. In the field, this would mean that the stiffness of these mixtures should be less sensitive to variations in the traffic speed, suggesting a high potential for their use along segments with a steep slope and slow traffic. In this regard, it is possible to establish a behavior hierarchy, where the mixture modified with both modifiers is at the top, followed by SBS $60 / 85,3 \% \mathrm{NC}$, and the conventional mixture.

It also can be noted in Figure 4 that the gains related to the frequency susceptibility of the modified mixtures are more significant at lower load frequencies (equivalent to higher temperatures). This may be considered a positive aspect in relation to the permanent deformation phenomenon in regions of tropical climate and on highways submitted to slow loads or in mountainous regions. 
Figure 5 shows the black spaces for the different asphalt mixtures.

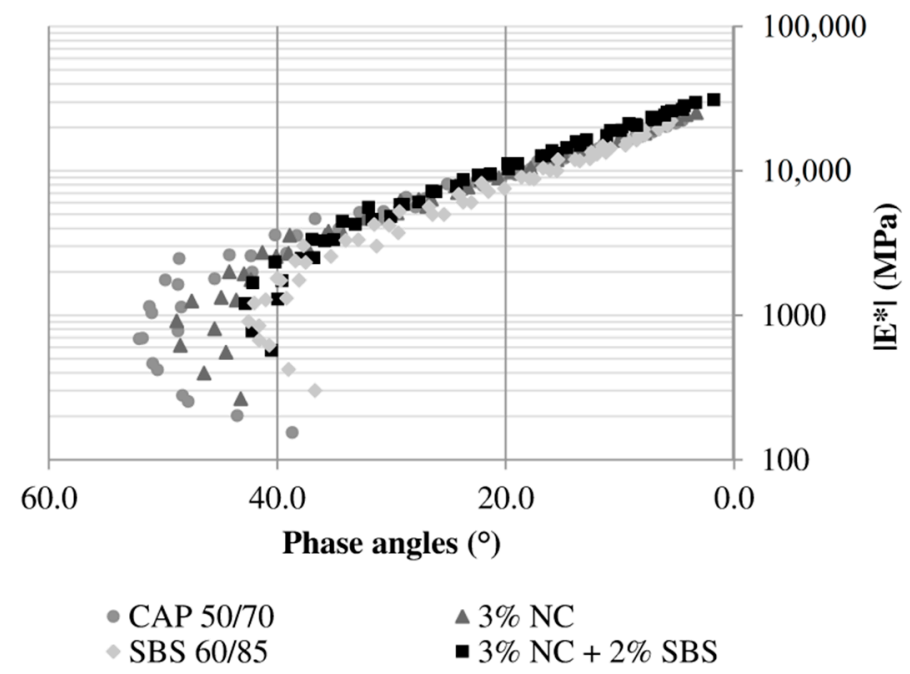

Figure 5. Black spaces.

It can be noted in Figure 5 that the modified mixtures present an aspect of graphic shortening (in relation to the phase angle) when compared with the conventional mixture. This shortening illustrates the obtainment of smaller phase angles and reflects the more elastic behavior of these mixtures. Of these, it can be observed that the 3\% NC $+2 \%$ SBS mixture has a higher concentration of low phase angles, followed by the SBS 60/85 mixture. The elastic behavior of them, both modified with SBS, reflects the influence of the presence of an elastomeric polymer in the binders. Considered in isolation, this would suggest a better performance of these mixtures in relation to their resistance to permanent deformation and to fatigue cracking.

\subsection{Resistance to Permanent Deformation}

In Figures 6 and 7, the curves obtained in the permanent deformation tests and the results for the rutting depth (\%) of mixtures after 30,000 cycles are provided, respectively.
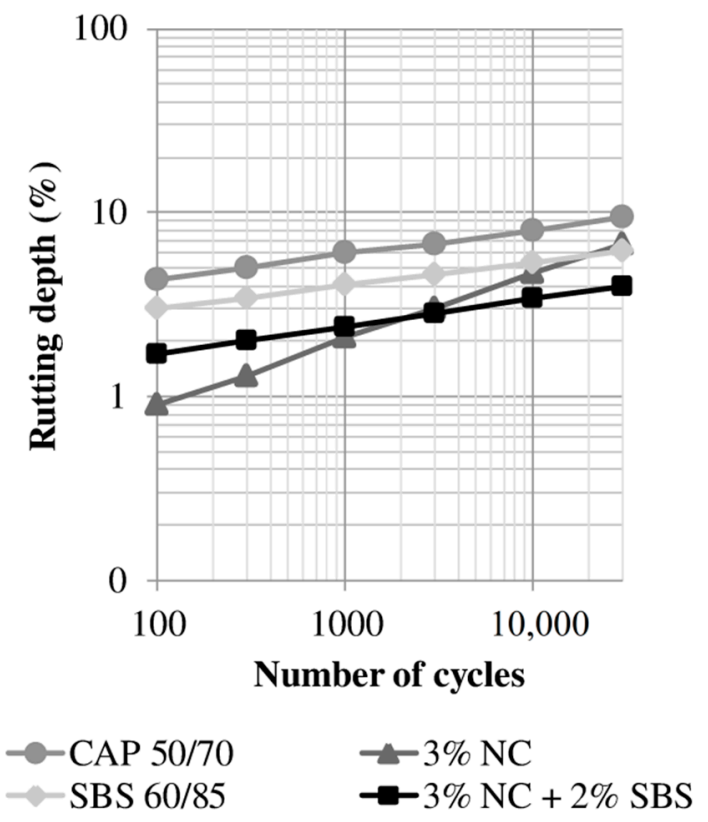

Figure 6. Curves obtained in permanent deformation tests. 


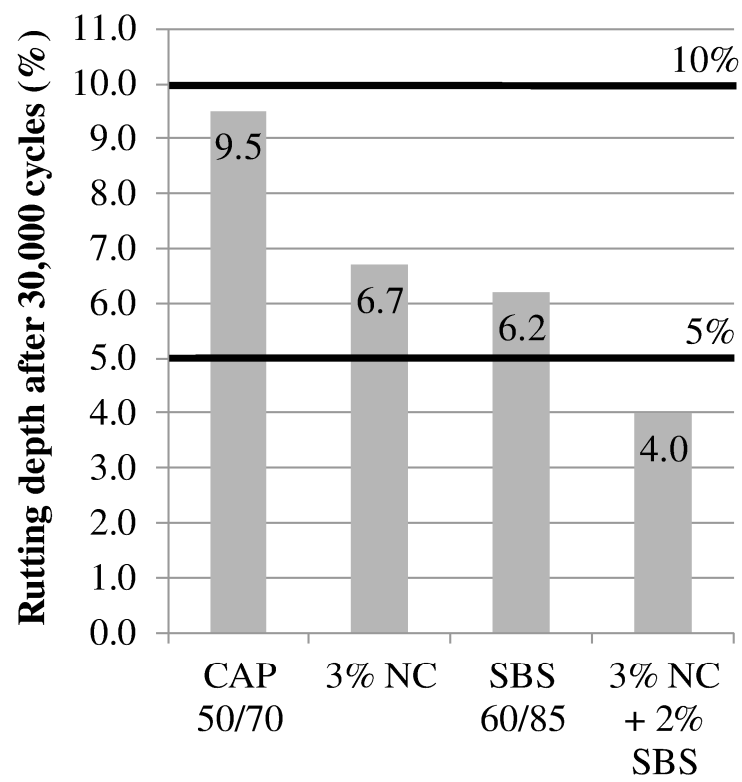

Figure 7. Results for rutting depth (\%) after 30,000 cycles.

According to the results shown in Figures 6 and 7, the resistance to permanent deformation, considering 30,000 load cycles was highest for the 3\% NC + 2\% SBS mixture, followed by the SBS $60 / 85,3 \% \mathrm{NC}$, and conventional mixtures. In proportional terms, in practice, it is estimated that the replacement of the conventional mixture containing the two modifiers would reduce the rutting depth in the field by up to $58 \%$. Considering the replacement of the reference mixture with the SBS 60/85 and $3 \%$ NC mixtures, the corresponding reductions could reach up to $35 \%$ and $29 \%$, respectively.

The best behavior in terms of permanent deformation observed for 3\% NC $+2 \%$ SBS mixture is in agreement with the performance prediction carried out in the empirical characterization of the binders (lower penetration) and the rheological study of the mixtures (higher stiffness and lower phase angles). In the same way, the results for the phase angles were also effective in the prediction of the performance hierarchy of the mixtures in relation to resistance to permanent deformation.

About the rate of deformation increase, which can be measured by the WTS (wheel-tracking slope) parameter, Figure 6 shows similar behaviors between the mixtures CAP 50/70, SBS 60/85, and 3\% NC + $2 \%$ SBS. On the other hand, it is observed that the 3\% NC mix exhibits a lower initial deformation with a higher deformation increase rate. In this sense, considering about 3000 load cycles, for example, the deformation level was the same for the mixtures 3\% NC and 3\% NC + 2\% SBS; however, due to a higher deformation increase of the mixture modified only by nanoclay, the scenario becomes different at the end of the test. High rates of deformation increase are considered a negative characteristic for asphalt mixtures performance, and according to the results obtained in this work, simultaneous action of SBS can improve this behavior of the 3\% NC mixture.

Regarding the maximum limits for the rutting depth established by the French [46] and the European [47] specifications, all of the asphalt mixtures under study met the $10 \%$ criterion for 30,000 load cycles. However, only the $3 \% \mathrm{NC}+2 \%$ SBS mixture satisfied the more restrictive criterion, corresponding to $5 \%$.

\subsection{Resistance to Fatigue Cracking}

The results of the fatigue tests are shown in Figure 8. Below the graph, the representative fatigue models of the mixtures are presented alongside the respective coefficients of determination $\left(R^{2}\right)$ and the specific deformations for $10^{6}$ cycles $\left(\varepsilon_{6}\right)$. The models relate the tensile strain $(\mu \varepsilon)$ applied on the specimens to the number of cycles ( $N$, loading applications) until asphalt concrete reaches $50 \%$ of initial stiffness. 


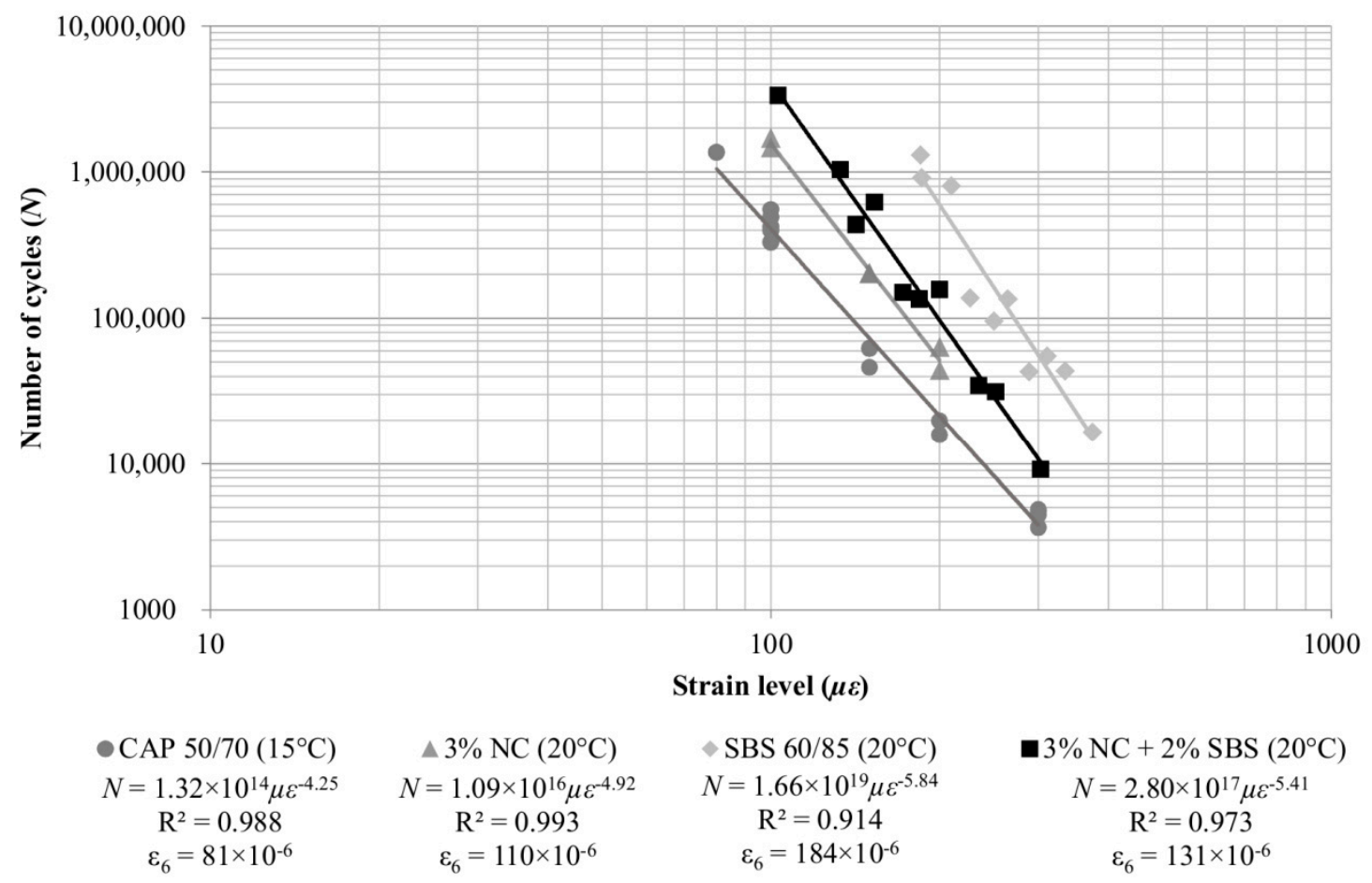

Figure 8. Curves obtained in fatigue tests.

For the conditions adopted in the tests carried out in this research, from the curves shown in Figure 8 , it can be observed the higher fatigue strength of the SBS $60 / 85$ mixture, followed by the 3\% $\mathrm{NC}+2 \% \mathrm{SBS}, 3 \% \mathrm{NC}$ and conventional mixtures.

Concerning the fatigue behavior prediction based on the rheological study, it can be noted that it was partially accomplished. In this sense, the superior behavior of the SBS 60/85 and 3\% NC + 2\% SBS mixtures was expected, due to the greater predominance of the elastic behavior (lower phase angles). However, according to the respective results, it was expected that the best performance would be of the $3 \%$ NC $+2 \%$ SBS mixture, in comparison to the SBS 60/85, which did not occur. Probably, in terms of fatigue, the mixture modified by nanoclay and SBS was impaired due to the considerable increase in the stiffness of the material, which was verified in the empirical characterization of the binder (low penetration) and also in the rheological study of the mixtures.

\subsection{Results of Numerical Simulations}

Table 9 presents the numerical simulation results applied to the fatigue models.

Table 9. Numerical simulations results applied to the fatigue models.

\begin{tabular}{cccc}
\hline Structure/Asphalt Surface & Strain $(\mu \varepsilon)$ & Fatigue Model & Number of Cycles (N) \\
\hline S1/Surface with CAP 50/70 & 65 & $N=1.32 \times 10^{14} \mu \varepsilon^{-4.25}$ & $2.60 \times 10^{6}$ \\
S2/Surface with 3\% NC & 75 & $N=1.09 \times 10^{16} \mu \varepsilon^{-4.92}$ & $6.49 \times 10^{6}$ \\
S3/Surface with SBS 60/85 & 80 & $N=1.66 \times 10^{19} \mu \varepsilon^{-5.84}$ & $1.28 \times 10^{8}$ \\
S4/Surface with 3\% NC + 2\% SBS & 61 & $N=2.80 \times 10^{17} \mu \varepsilon^{-5.41}$ & $6.15 \times 10^{7}$ \\
\hline
\end{tabular}

From the results presented in Table 9, the following hierarchy can be established for the asphalt mixtures, in terms of fatigue lifespan, starting by the longest one: structure S3 (surface with SBS 60/85 mixture), structure S4 (surface with 3\% NC + 2\% SBS mixture), structure S2 (surface with 3\% NC mixture), and structure $\mathrm{S} 1$ (surface with conventional mixture).

First, comparing the structures S1 and S2, it could be observed that the use of the 3\% NC mixture, in substitution to the conventional one, would represent an increase of 1.5 times in the fatigue lifespan 
of the surface. When the same comparison is carried out between the S1 and S4 structures, it is noted that the simultaneous addition of the polymer to the nanoclay modified mixture would enhance these gains to about 23 times. However, despite the high performance of the 3\% NC $+2 \%$ SBS mixture and keeping the thicknesses of the layers, it is noted that the use of the SBS 60/85, in substitution to the mixture modified simultaneously by nanoclay and polymer, would double the fatigue lifespan of the surface. In this sense, looking for the equivalent performance of these two mixtures, it requires an increase in the thickness of the $3 \% \mathrm{NC}+2 \%$ SBS modified surface. Even so, considering a possibility of cost reduction from the substitution of the SBS $60 / 85$ mixture by the 3\% NC $+2 \%$ SBS (due to the lower polymer content), it is expected that this substitution, besides being technically feasible, could also be economically viable. This finding highlights the application potential of the $3 \% \mathrm{NC}+2 \%$ SBS mixture, which may present as a competitive alternative to the other mixtures studied.

\section{Conclusions}

According to the objective previously defined, this study enabled four different asphalt mixtures to be compared in terms of their rheological behavior, resistance to permanent deformation, and resistance to fatigue cracking. The mixtures were prepared with different binders as follows: conventional (CAP $50 / 70)$, modified with nanoclay ( $3 \%$ NC), modified with SBS polymer (SBS 60/85), and modified with both nanoclay and SBS ( $3 \% \mathrm{NC}+2 \% \mathrm{SBS})$.

Based on the results obtained in this study, the mixture modified with the binder $3 \% \mathrm{NC}+2 \%$ SBS showed a better rheological behavior and a higher resistance to permanent deformation. This mixture presented the highest values for the complex modulus and the lowest phase angles, which is considered an indication of higher resistance to rutting. In the permanent deformation tests, it showed the lowest percentage of rutting depth, thus confirming the predictions based on the rheological study.

On the other hand, considering the fatigue tests results, a better resistance was observed in the SBS 60/85 mixture. In this respect, the predictions made according to the rheological behavior were partially verified. Even so, on the next stage of this study, numerical simulations of pavement structures demonstrated the use of the 3\% NC $+2 \%$ SBS surface as a replacement for the SBS 60/85 being technically viable (with thickness adjustments), and considering the possibility of reducing costs from this substitution, it could also be economically viable. In this sense, considering the costs of the materials used in the research, it is believed that the mixture modified by nanoargila and SBS (with lower content) would be cheaper than that modified by a higher SBS content. However, economic viability with specific comparisons should be verified in future studies.

Thus, it is concluded that the use of polymers science together with the application of nanotechnology can lead to great advances in the area of modified asphalt mixtures for use on roadways where a higher performance of the paving materials is required. Especially in relation to rutting, it is highlighted that this alternative has great potential to provide improved asphalt surfaces, mainly in regions of tropical climate and on highways submitted to slow heavy traffic.

Author Contributions: Conceptualization, G.C.C., G.T., J.V.S.d.M. and M.F.M.; methodology, G.C.C., G.T., J.V.S.d.M. and M.F.M.; formal analysis, G.C.C., G.T., J.V.S.d.M., M.F.M., L.P.T. and L.C.d.L.; investigation, G.C.C., G.T., J.V.S.d.M. and M.F.M.; writing-original draft preparation, G.C.C. and T.G.; writing-review and editing, G.C.C., G.T., J.V.S.d.M., M.F.M., L.P.T. and L.C.d.L.

Funding: This research was funded by NATIONAL COUNCIL FOR SCIENTIFIC AND TECHNOLOGICAL DEVELOPMENT (CNPq), grant number 130697/2015-0, and by ASPHALT TECHNOLOGY NETWORK/PETROBRAS, grant number 2014/00282-9.

Acknowledgments: The authors would like to thank the National Council for Scientific and Technological Development $(\mathrm{CNPq})$, and the Asphalt Technology Network/Petrobras. We are also grateful to Greca Asfaltos S.A. (for supplying the binders CAP 50/70 and SBS 60/85) and to Kraton (for providing the SBS polymer).

Conflicts of Interest: The authors declare no conflict of interest. 


\section{References}

1. Bernucci, L.B.; Motta, L.M.G.; Ceratti, J.A.P.; Soares, J.B. Pavimentação Asfáltica: Formação Básica Para Engenheiros; Petrobras ABEDA: Rio de Janeiro, Brazil, 2008.

2. Ashish, P.K.; Singh, D.; Bohm, S. Investigation on influence of nanoclay addition on rheological performance of asphalt binder. Road Mater. Pavement Des. 2016, 18, 1007-1026. [CrossRef]

3. Cavalcanti, L.S. Efeito de Alguns Modificadores de Ligante Na Vida de Fadiga e Deformação Permanente de Misturas Asfálticas. Master's Thesis, Programa de Pós-Graduação em Engenharia Civil, COPPE, Universidade Federal do Rio de Janeiro, Rio de Janeiro, Brazil, 2010.

4. Crucho, J.M.P.; Neves, J.M.C.; Capitão, S.D.; Picado-Santos, L.G. Mechanical performance of asphalt concrete modified with nanoparticles: Nanosilica, zero-valent iron and nanoclay. Constr. Build. Mater. 2018, 181, 309-318. [CrossRef]

5. Goh, S.W.; Akin, M.; You, Z.; Shi, X. Effect of deicing solutions on the tensile strength of micro or nano-modified asphalt mixture. Constr. Build. Mater. 2011, 25, 195-200. [CrossRef]

6. Iskender, E. Evaluation of mechanical properties of nano-clay modified asphalt mixtures. Measurement 2016, 93, 359-371. [CrossRef]

7. Jahromi, S.G.; Andalibizade, B.; Vossough, S. Engineering properties of nanoclay modified asphalt concrete mixtures. Arab. J. Sci. Eng. 2010, 35, 89-103.

8. Jahromi, S.G.; Khodaii, A. Effects of nanoclay on rheological properties of bitumen binder. Constr. Build. Mater. 2009, 23, 2894-2904. [CrossRef]

9. Leite, L.F.M.; Guerra, G.; Martins, A.; Cravo, M. Efeito de nanomodificadores no envelhecimento e susceptibilidade térmica de cimentos asfálticos. In Proceedings of the $41^{\mathrm{a}}$ Reunião Anual de Pavimentação. Fortaleza, Ceará, Brazil, 3-5 November 2012.

10. You, Z.; Mills-Beale, J.; Foley, J.; Roy, S.; Odegard, G.; Dai, Q.; Goh, S.W. Nanoclay-modified asphalt materials preparation and characterization. Constr. Build. Mater. 2011, 25, 1072-1078. [CrossRef]

11. Yu, J.; Feng, P.; Zhang, H.; Wu, S. Effect of organo-montmorillonite on aging properties of asphalt. Constr. Build. Mater. 2009, 23, 2636-2640. [CrossRef]

12. Zare-Shahabadi, A.; Shokuhfar, A.; Ebrahimi-Nejad, S. Preparation and rheological characterization of asphalt binders reinforced with layered silicate nanoparticles. Constr. Build. Mater. 2010, 24, 1239-1244. [CrossRef]

13. Babagoli, R.; Mohammadi, R.; Ameri, M. The rheological behavior of bitumen and moisture susceptibility modified with SBS and nanoclay. Pet. Sci. Technol. 2017, 35, 1085-1090. [CrossRef]

14. Cai, L.; Shi, X.; Xue, J. Laboratory evaluation of composed modified asphalt binder and mixture containing nano-silica/rock asphalt/SBS. Constr. Build. Mater. 2018, 172, 204-211. [CrossRef]

15. Farias, L.G.A.T.; Leitinho, J.L.; Amoni, B.C.; Bastos, J.B.S.; Soares, J.B.; Soares, S.A.; Sant'ana, H.B. Effects of nanoclay and nanocomposites on bitumen rheological properties. Constr. Build. Mater. 2016, 125, 873-883. [CrossRef]

16. Galooyak, S.S.; Dabir, B.; Nazarbeygi, A.E.; Moeini, A. Rheological properties and storage stability of bitumen/SBS/montmorillonite composites. Constr. Build. Mater. 2010, 24, 300-307. [CrossRef]

17. Golestani, B.; Nam, B.H.; Nejad, F.M.; Fallah, S. Nanoclay application to asphalt concrete: Characterization of polymer and linear nanocomposite-modified asphalt binder and mixture. Constr. Build. Mater. 2015, 91, 32-38. [CrossRef]

18. Golestani, B.; Nejad, F.M.; Galooyak, S.S. Performance evaluation of linear and nonlinear nanocomposite modified asphalts. Constr. Build. Mater. 2012, 35, 197-203. [CrossRef]

19. Merusi, F.; Giuliani, F.; Filippi, S.; Polacco, G. A model combining structure and properties of 160/220 bituminous binder modified with polymer/clay nanocomposites. A rheological and morphological study. Mater. Struct. 2014, 47, 819-838. [CrossRef]

20. Pamplona, T.F.; Amoni, B.C.; Alencar, A.E.V.; Lima, A.P.D.; Ricardo, N.M.P.S.; Soares, J.B.; Soares, S.A. Asphalt binders modified by SBS and SBS/nanoclays: Effect on rheological properties. J. Braz. Chem. Soc. 2012, 23, 639-647. [CrossRef]

21. Zhang, H.; Su, M.; Zhao, S.; Zhang, Y.; Zhang, Z. High and low temperature properties of nano-particles/polymer modified asphalt. Constr. Build. Mater. 2016, 114, 323-332. [CrossRef] 
22. Melo, J.V.S. Desenvolvimento E Estudo Do Comportamento Reológico E Desempenho Mecânico De Concretos Asfálticos Modificados Com Nanocompósitos. Ph.D. Thesis, Pós-Graduação Em Engenharia Civil, Universidade Federal De Santa Catarina, Florianópolis, Brazil, 2014.

23. Marcon, M.F. Estudo e Comparação do Desempenho Mecânico e Reológico Entre Concretos Asfálticos Modificados Por Polímero SBS, Borracha Moída de Pneu e Nanomateriais. Master's Thesis, Pós-Graduação em Engenharia Civil, Universidade Federal de Santa Catarina, Florianópolis, Brazil, 2016.

24. Carlesso, G.C. Estudo do Comportamento de Mistura Asfáltica Modificada Por Nanoargila e Polímero SBS. Master's Thesis, Pós-Graduação em Engenharia Civil, Universidade Federal de Santa Catarina, Florianópolis, Brazil, 2017.

25. ASTM-American Society for Testing Materials. ASTM C 127: Standard Test Method for Density, Relative Density (Specific Gravity), and Absorption of Coarse Aggregate; ASTM: West Conshohocken, PA, USA, 2012.

26. DNER-Departamento Nacional de Estradas de Rodagem. DNER-ME 084: Agregado Miúdo-Determinação da Densidade Real; Método de ensaio; Instituto de Pesquisas Rodoviárias: Rio de Janeiro, Brazil, 1995.

27. DNER-Departamento Nacional de Estradas de Rodagem. DNER-ME 085: Material Finamente PulverizadoDeterminação da Massa Especifica Real; Método de ensaio; Instituto de Pesquisas Rodoviárias: Rio de Janeiro, Brazil, 1994.

28. ASTM-American Society for Testing Materials. ASTM D 5821: Standard Test Method for Determining the Percentage of Fractured Particles in Coarse Aggregate; ASTM: West Conshohocken, PA, USA, 2013.

29. ASTM-American Society for Testing Materials. ASTM C 1252: Standard Test Methods for Uncompacted Void Content of Fine Aggregate (as Influenced by Particle Shape, Surface Texture, and Grading); ASTM: West Conshohocken, PA, USA, 2006.

30. ABNT-Associação Brasileira de Normas Técnicas. ABNT NBR 6954: Lastro-Padrão-Determinação da Forma do Material; ABNT: Rio de Janeiro, Brazil, 1989.

31. AASHTO-American Association of State Highway and Transportation. AASHTO T 176: Standard Method of Test for Plastic Fines in Graded Aggregates and Soils by Use of the Sand Equivalent Test; Test standard specifications for transportation materials and methods of sampling and testing; AASHTO: Washington, DC, USA, 2008.

32. ASTM-American Society for Testing Materials. ASTM C 131: Standard Test Method for Resistance to Degradation of Small-Size Coarse Aggregate by Abrasion and Impact in the Los Angeles Machine; ASTM: West Conshohocken, PA, USA, 2014.

33. ASTM-American Society for Testing Materials. ASTM C 88: Standard Test Method for Soundness of Aggregates by Use of Sodium Sulfate or Magnesium Sulfate; ASTM: West Conshohocken, PA, USA, 2013.

34. AASHTO-American Association of State Highway and Transportation. AASHTO T 112: Standard Method of Test for Clay Lumps and Friable Particles in Aggregates; Test standard specifications for transportation materials and methods of sampling and testing; AASHTO: Washington, DC, USA, 2012.

35. ASTM-American Society for Testing Materials. ASTM D 5: Standard Test Method for Penetration of Bituminous Materials; ASTM: West Conshohocken, PA, USA, 2013.

36. ASTM-American Society for Testing Materials. ASTM D 36-Standard Test Method for Softening Point of Bitumen (Ring-and-Ball Apparatus); ASTM: West Conshohocken, PA, USA, 2014.

37. ASTM-American Society for Testing Materials. ASTM D 4402-Standard Test Method for Viscosity Determination of Asphalt at Elevated Temperatures Using a Rotational Viscometer; ASTM: West Conshohocken, PA, USA, 2013.

38. ABNT-Associação Brasileira de Normas Técnicas. ABNT NBR 15086: Materiais Betuminosos-Determinação da Recuperação Elástica Pelo Ductilômetro; ABNT: Rio de Janeiro, RJ, Brazil, 2006.

39. Martinho, F.C.G.; Farinha, J.P.S. An overview of the use of nanoclay modified bitumen in asphalt mixtures for enhanced flexible pavement performances. Road Mater. Pavement Des. 2017, 20, 1-31. [CrossRef]

40. ABNT-Associação Brasileira de Normas Técnicas. ABNT NBR 15166: Asfalto Modificado-Ensaio de Separação de Fase; ABNT: Rio de Janeiro, RJ, Brazil, 2004.

41. AASHTO-American Association of State Highway and Transportation. AASHTO M 323: Standard Specification for Superpave Volumetric Mix Design; Test standard specifications for transportation materials and methods of sampling and testing; AASHTO: Washington, DC, USA, 2013.

42. AASHTO-American Association of State Highway and Transportation. AASHTO R 35: Standard Practice for Superpave Volumetric Design for Hot-Mix Asphalt (HMA); Test standard specifications for transportation materials and methods of sampling and testing; AASHTO: Washington, DC, USA, 2012. 
43. AFNOR-Association Française de Normalisation. AFNOR NF P 98-250-2-Essais Relatifs Aux Chaussées, Preparation des Mélanges Hydrocarbonés, Partie 2: Compactage des Plaques; AFNOR: Paris, France, 1991.

44. CEN-European Committee for Standardization. EN 12697-26-Bituminous Mixtures, Test Methods for Hot Mix Asphalt-Part 26: Stiffness; CEN: Brussels, Belgium, 2004.

45. CEN-European Committee for Standardization. EN 12697-22+A1-Mélanges Bitumineux-Méthodes D'essai Pour Mélange Hydrocarboné à Chaud-Partie 22: Essai D'orniérage; CEN: Brussels, Belgium, 2007.

46. LCPC-Laboratoire Central des Ponts et Chaussées. Manuel LPC d'aide à La Formulation des Enrobés à Chaud: Groupe de travail RST Formulation des enrobés à chaud; LCPC: Paris, France, 2007.

47. COST 333. Development of New Bituminous Pavement Design Method: Final Report of the Action; European Cooperation in the field of Scientific and Technical Research; European Commission Directorate General Transport: Brussels, Belgium, 1999.

48. CEN-European Committee for Standardization. EN 12697-24-Bituminous Mixtures, Test Methods for Hot Mix Asphalt-Part 24: Resistance to Fatigue; CEN: Brussels, Belgium, 2004.

49. Chabot, A.; Chupin, O.; Deloffre, L.; Duhamel, D. Viscoroute 2.0: A tool for simulation of moving load effects on asphalt pavement. Road Mater. Pavement Des. 2010, 11, 227-250. [CrossRef]

50. ANP-Agência Nacional De Petróleo, Gás e Biocombustível; Resolução ANP nº 32ANP: Brasília DF, Brazil, 2010.

(C) 2019 by the authors. Licensee MDPI, Basel, Switzerland. This article is an open access article distributed under the terms and conditions of the Creative Commons Attribution (CC BY) license (http://creativecommons.org/licenses/by/4.0/). 